\title{
Yrittäjyyden edistämisen kiperät ja kriittiset kysymykset yliopistoissa
}

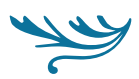

Sivistysyliopisto ja yrittäjyysyliopisto eivät ole vastakkaisia tavoitteita. Yrittäjyyden edistäminen yliopistoissa kestävästi edellyttää yliopistotoimijoilta kriittisyyttä ja refleksiivisyyttä.

YRITTÄJYYS ON LÖYTÄNYT TIENSÄ kaikille opetusasteille ja oppilaitoksiin. Millaisia haasteita yrittäjyyden edistämiseen yliopistoissa sisältyy?

Keskityn kysymyksiin, jotka koskevat yrittäjyyden esittämistä itsestään selvänä vaihtoehtona ja mahdollisuutena kaikille yliopisto-opiskelijoille. Itsestäänselvyydet tekevät kysymyksistä erityisen kiperiä ja vaikeita tunnistaa, jolloin niihin on mahdotonta tarttua. Tarkastelen samalla kriittisesti sitä, miten ymmärrämme yrittäjyyden ja miten yrittäjyyttä opetetaan. Lopuksi tuon esiin, miten kriittisyys ja refleksiivisyys voivat tukea yrittäjyyden edistämistä yliopistoissa.

Yrittäjyyskasvatuksen perinteet ulottuvat Suomessa 1980-luvulle. Nousukaudella se esitettiin tavaksi, jolla varmistetaan kansantalouden myönteinen kehitys vastaisuudessakin. Ammatillisessa koulutuksessa lakiin nostettiin yhdeksi tavoitteeksi yrittäjyyteen pe- rehdyttäminen 1980-luvun loppupuolella. Yleissivistävän koulutuksen opetusohjelmiin yrittäjyyskasvatus tuli 1990-luvun puolivälissä (Ikonen 2006).

Opetussuunnitelmauudistuksessa yrittäjyyskasvatuksen asemaa opetussuunnitelmissa vahvistettiin edelleen 2000-luvun puolivälissä (Seikkula-Leino 2007). Samaan aikaan ammattikorkeakouluissa on laadittu yrittäjyysstrategioita, ja monissa yliopistoissa on vahvistettu yrittäjyysopetuksen saatavuutta läpi tiedekuntien ja opetusohjelmien. Tuoreimmat yliopistojen, ammattikorkeakoulujen ja Suomen Yrittäjät -järjestön yhteiset yrittäjyyssuositukset julkistettiin loppuvuodesta 2018 (Korkeakoulujen yrittäjyyssuositukset 2018).

Yrittäjyyden tutkijana ja opettajana yrittäjyysyliopistoksi profiloituvassa Turun yliopistossa minun siis pitäisi olla erittäin tyytyväinen asioiden tilaan ja 


\section{YRITT ÄJYYSOPETUKSEN}

\section{SAATAVUUTTA ON VAHVISTETTU \\ L ̈̈PI TIEDEKUNTIEN JA \\ OPETUSOHJELMIEN.}

tolaan: yrittäjyys on vahvasti esillä, ja sitä halutaan voimakkaasti edistää opetuksessa ja koulutuksessa. Kriittiselle näkemykselle ja kysymyksille on kuitenkin uskoakseni tilaa ja tarvetta yliopistojen yrittäjyysstrategioissa ja -tavoitteissa (Hytti 2018).

Yrittäjyyden ponnekas edistäminen ilman kriittistä arviointia johtaa väärinymmärryksiin.

\section{KAIKISTA YLIOPISTO-OPISKELIJOISTAKO YRITTÄJIÄ?}

Ensinnä nostan keskusteluun opiskelijoiden yrittäjäksi ryhtymisen tavoitteen. Arkipuheessa kaikkien korkeakouluopiskelijoiden yrittäjyysmyönteisyyttä ja yrittäjyyden tavoittelua omana uravalintana pidetään itsestään selvänä päämääränä, jota yliopistoissa pitäisi tavoitella. Yrittäjyystutkija Scott Shane on esittänyt, että kansantalouden kannalta yrittäjien määrän lisääminen ei ole järkevä tavoite. Sen sijaan valtioiden kannattaisi tukea kasvuyrittäjyyttä (Shane 2009).

Yliopistoissa tavoite ei pitäisi olla kaikkien tai mahdollisimman monen opiskelijan johdattelu, kannustaminen tai motivoiminen yrittäjyyteen vaan yrittäjäksi ryhtymisestä kiinnostuneen, melko harvalukuisen joukon yrittäjyysvalmiuksien ja -osaamisen kehittäminen siten, että yritykset kasvavat ja kansainvälistyvät - ja luovat työpaikkoja myös muille (mt).

Vastoin Shanen toiveita monissa maissa, kuten Suomessa, erityisesti yksinyrittäjien määrä on lisääntynyt voimakkaasti aina viime vuosiin saakka (Sutela \& Pärnänen 2018). Yrittäjäksi ryhtymisen ideaalin muuttumista itsestäänselvyydeksi kuvaavat erilaiset mittarit. Yrittäjäksi ryhtyvien tai yrittäjyyttä pohtivien opiskelijoiden vähyys esitetään ongelmaksi tai yliopistojen haasteeksi. Voimme kuitenkin olla ajautumassa tilanteeseen, jossa kansantaloudessamme yksinyrittäjien suhteellinen osuus kaikkien yritysten ja varsinkin kasvuyritysten lukumäärästä on suhteettoman suuri eikä suinkaan optimaalinen. (Shane 2009)

Shane tarkastelee asiaa kansantalouden näkökulmasta. Talouden näkökulma on kuitenkin tärkeä myös yksilölle. Tiedetään, että yrittäjien tulot ovat polarisoituneet, ja juuri yksinyrittäjien väliset tuloerot ovat suurimmat. Suomessa peräti neljännes yksinyrittäjistä sijoittui vuonna 2017 alimpaan tuloluokkaan (Sutela \& Pärnänen 2018). Pienet tulot voivat toki olla elämäntyyliin ja esimerkiksi työajan rajaamista koskeva henkilökohtainen ratkaisu. Silti yliopistoissa on syytä pohtia, tukeeko yrittäjyyden ylikorostaminen yliopistoissa uuden "köyhien yrittäjien" luokan muodostumista.

\section{YRITTÄJYYS TALOUDELLISENA, VOITTOA TAVOITTELEVANA TOIMINTANA?}

Toiseksi yrittäjyysopetuksen edistäminen kutsuu pohtimaan eettisiä ja vastuullisuutta koskevia kysymyksiä. Koko maailmaa vuonna 2008 ravisuttaneen pankkikriisin jälkeen kauppakorkeakoulut haastettiin vahvasti pohtimaan opetuksen eettisiä kysymyksiä. Yrittäjyysopetuksen eettisiin kysymyksiin perehtynyt David Rae toteaa, että yrittäjyysopetuksessa ei voi enää keskittyä liiketaloudellisesti kannattavan liiketoimintamahdollisuuden hyödyntämiseen, vaan opetuksen olisi tuettava eettisesti ja ympäristöllisesti kestävien liiketoimintamahdollisuuksien valikoitumista, esimerkiksi luonnonvaroja säästäen ja uudelleen käyttäen. Liiketoimintamahdollisuuksia ei voi tarkastella vain yksilön vaan laajemman yhteisön tai yhteiskunnan kannalta (Rae 2014).

Esimerkistä käyvät pikavippiyritykset. Vaikka pikavippitoiminta on yksittäiselle yrittäälle ja yritykselle kannattavaa liiketoimintaa, voidaanko jättää huomiotta vippien seurannaisvaikutukset yhteiskunnassa, esimerkiksi nuorten velkaantuminen, luottotietojen menetys ja sitä kautta vahvistunut syrjäytyminen?

Kolmanneksi voidaan pohtia, miten kapeasti tai laveasti ymmärrämme yrittäjyyden sisällön ja tavoitteet. Yrittäjyyden ymmärtäminen suppeasti vain talouskasvun moottoriksi pitää yllä konsensusta, että yrittäjyyden ytimessä on uusien liiketoiminta- 


\section{YRITTÄJYYSOPETUKSESTA \\ ON TULLUT}

PIKARUOKAKIOSKI.

mahdollisuuksien tavoittelu, uusien yritysten perustaminen ja kasvu, riskinotto ja resurssien hankkiminen ja allokointi (Kyrö 2015). 2000-luvulla yrittäjyydelle on kuitenkin annettu ja nostettu muitakin rooleja, esimerkiksi yrittäjyys yhteiskunnallisten haasteiden ja ongelmien ratkomiseksi yhteiskunnallisen yrittäjyyden kautta (ks. Peredo \& McLean 2006).

\section{YHDENMUKAISTA YRITTÄJYYSOPETUSTA KAIKILLE?}

Neljänneksi on pohdittava kriittisesti yrittäjyysopetusta ja sen didaktisia ja pedagogisia ratkaisuja. Yhdeksi ongelmaksi on tunnistettu yliopisto-opetuksen mcdonaldistuminen eli opetuksen kehittäminen pikaruokalaperiaatteiden mukaisesti (Ritzer 1998). Se tarjoaa mielenkiintoisen viitekehyksen myös yrittäjyysopetuksen tarkasteluun (Hytti 2018). Amerikkalaisten, konsulttivetoisten menetelmien ja työkalujen käyttäminen on muodostunut yrittäjyysopetuksessa lähes kaanoniksi (Blank 2013a; Blank 2013b; Ries 2011). Tiimit ideoivat uutta liiketoimintaa hyödyntämällä liiketoimintamallien kehittämiseen laadittuja työkaluja ja esittelevät yritysideoita eli pitchaavat kuvitelluille sijoittajille vakioidun kaavan mukaisesti. Opetuksessa hyödynnetään yrittäjiä vierailuluennoijina, vietetään oppimisjaksoja PK-yrityksissä tai varjostetaan yrittäjiä. Vakiomuotoinen opetus jättää verrattain vähän tilaa innovatiiviselle opetusmenetelmien kehittämiselle. Yrittäjyysopetuksesta on tullut pikaruokakioski, jonka luukusta tarjoillaan samaa tuotetta, olipa opiskelija sitten Piilaaksossa, Suomessa tai Perussa (Hytti 2018).

Viime vuosina onkin nostettu esiin tarve yrittäjyysopetuksen uudelleenajattelulle, jossa toivotetaan tervetulleeksi itsestään selvien opetusmenetelmien kyseenalaistaminen, uusien innovatiivisten ja esimerkiksi opiskelijoiden lähtökohdista yhä paremmin ponnistavien menetelmien kehittäminen (Berglund \& Verduyn 2018). Yrittäjyysopetuksen uudelleenajattelu luo tilaa paitsi opettajien myös opiskelijoiden omalle pohdinnalle.

Usein yrittäjyyskasvatusta tarkastelevissa artikkeleissa korostetaan kokemukselliseen oppimiseen perustuvan opetuksen ylivertaisuutta tai paremmuutta esimerkiksi luento-opetukseen verrattuna. Kuitenkaan tutkimusevidenssi ei tue näitä väitteitä. Inna Kozlinzkan (2016) liiketaloustieteellisessä yrittäjyyskasvatuksen alan väitöskirjatutkimuksessa vertailtiin eri tavoin toteutetun yrittäjyysopetuksen vaikutuksia osaamiseen, asenteisiin sekä valmistumisen jälkeiseen työllistyvyyteen, sisäiseen yrittäjyyteen ja varhaisen vaiheen yrittäjyyteen Virossa ja Latviassa. Tutkimuksessa havaittiin, että kokemukseen eli tekemällä oppimiseen perustuva yrittäjyysopetus ei välttämättä tuota parempia tuloksia kuin perinteinen, luentoihin perustuva yrittäjyysopetus. Päinvastoin, kokemuksellisesta yrittäjyysopetuksesta näytti olevan jopa haittaa. Se edellyttää, että opiskelijoiden on osattava oppia kokemuksesta: reflektoida ja ymmärtää oppimaansa (ks. myös Hägg 2017).

\section{SUKUPUOLI SELITTÄÄ YRITTÄJYYSAIKOMUKSIA}

Viides mahdollinen ongelma koskee opiskelijoiden tarkastelemista yhtenä, homogeenisena ryhmänä, joille voidaan tarjota samaa yrittäjyysopetusta ottamatta huomioon esimerkiksi sukupuolta, luokkaa tai opiskelualaa. Yrittäjyyteen liittyy vahvoja stereotyyppisiä käsityksiä. Sitä pidetään maskuliinisena, miesten toimintana, jossa voitontavoitteluun tähtäävät uudet yritykset ovat keskiössä (Kyrö 2015).

Teen usein opetukseni alussa pienen testin, jossa pyydän opiskelijoita visualisoimaan mielessään eteensä yrittäjän. Useimmiten opiskelijat kuvittelevat miespuolisen yrittäjän. Tutkimusten perusteella sukupuoli selittää vahvasti yrittäjyysaikomuksia niin Suomessa kuin kansainvälisesti: yrittäjyyden perustamisaikeissa miehet ovat aktiivisempia kuin naiset (Wilson, Kickul \& Marlino 2007).

Siten olisi naiivia väittää, että pelkästään yrittäjyysopetuksen lisääminen tarjoaisi yhtäläiset mahdollisuudet kaikille lähestyä yrittäjyyttä sukupuolesta 
riippumatta. Esimerkiksi yrittäjyyskasvatuksen tutkijat Sally Jones ja Jan Warhuus nostavat artikkelissaan (2018) kiinnostavasti esiin, miten yrittäjyyden kurssikuvauksissa käytetään usein hyvin maskuliinista kieltä ja samalla tuotetaan käsityksiä siitä, keille kurssi soveltuu ja keille ei.

Yrittäjyysopetuksen esitemateriaalien kuvasto voi samoin vahvistaa yrittäjyyttä koskevia stereotypioita. Kurssiesitteen tekstissä ilmaistu yrittäjyyskurssin soveltuvuus kaikille saa uudenlaisen tulkintakehyksen, jos esitteen kuvituksessa miesopiskelijat istuvat kannettavien tietokoneiden takana.

Vuosina 2004-2005 Turun kauppakorkeakoulu toteutti yrittäjyyskurssin luonnontieteellisen tutkijakoulun jatko-opiskelijoille. Kurssin aluksi havaitsimme, että noin puolet opiskelijoista ei ollutkaan kovin innostuneita pohtimaan omaa yritystoimintaa, vaan he hakivat kurssilta tukea oman liiketoiminnallisen ymmärryksensä lisäämiseksi. Kurssiaineistoja analysoidessamme huomasimme, että naisopiskelijoiden oli vaikeaa edes pohtia omaa, teknologista tutkimusalaa koskevaa yrittäjyysmahdollisuutta. Heidän oli luontevampaa omaksua sisäisen yrittäjyyden käsite oman yrittäjyyden hahmottamiseksi tai pohtia yrittäjäksi ryhtymistä muille aloille, kuten palvelualoille (Hytti \& Heinonen 2013).

Teknologiayrittäjyys on erittäin miehinen toimiala, joten sille hakeutuvat naiset navigoivat sukupuolittuneiden odotusten ja käsitysten maastossa (Marlow \& McAdam 2013). Teknologian ja yrittäjyyden tiukka sidos yrittäjyyskursseissa voi luoda esteitä paitsi yrittäjyyttä pohtivien sukupuolen myös näiden edustamien eri oppiaineiden ja tiedekuntien näkökulmista. Vahva teknologinen lataus kurssilla lähettää piiloviestin esimerkiksi humanististen aineiden opiskelijoille, että tarjottu opetus ei sovellu heille tai houkuttele heitä.

Sibylle Heilbrunnin ja Tamar Almorin (2014) Israelissa tekemässä tutkimuksessa havaittiin, että yrittäjyyskasvatusohjelmalla voidaan vahvistaa oppilaiden välistä sosiaalista epätasa-arvoa. Yrittäjyyskasvatus tuotti hyviä tuloksia kouluissa, joiden oppilaat olivat keskiluokkaisista tai ylemmän yhteiskuntaluokan perheistä. Niissä kouluissa, joiden oppilaat olivat alemman yhteiskuntaluokan perheistä, yrittäjyys- kasvatus ei kehittänyt oppilaiden yrittäjyysosaamista, ja heidän kokemansa pystyvyys yrittäjyyteen heikkeni ohjelman myötä. Yhtenä selityksenä esitettiin oppilaiden vanhempien sitoutuneisuus tai sen puute yrittäjyyskasvatusohjelman tavoitteisiin (Heilbrunn \& Almor 2014).

Yrittäjyydessä resurssit, esimerkiksi verkostot, ovat keskeisiä (Jarillo 1989). Heilbrunnin ja Almorin (2014) tutkimuksessa nostettiin esiin, että perheen luokka-asemasta riippuvat resurssit ovat yhteydessä oppimistuloksiin jo perusopetuksessa. Tutkijat esittävätkin, että yhden yhtenäisen mallin sijaan tarvitaan yrittäjyyskasvatuksen räätälöintiä. Vastaavaa keskustelua ja pohdintaa - samoin kuin tutkimusta aiheesta - kaivataan yliopistoista.

Korkeakoulukontekstissa on tutkittu sitä, miten opiskelijoiden kulttuurinen ja etninen moninaisuus haastaa yliopisto-opetusta esimerkiksi kauppakorkeakouluissa. Tutkimusten perusteella pedagogisessa suunnittelussa pitäisi ottaa huomioon opiskelijoiden aiemmat kokemukset (Jabbar \& Hardaker 2013). Opiskelijat eivät ole homogeeninen joukko, joten yrittäjyysopetuksen kehittämisessä ja opetuksessa on oltava vastaanottavainen pohdinnalle esimerkiksi sukupuolesta, luokka-asemasta ja etnisyydestä, eikä voi naiivisti olettaa, että kaikilla on samat mahdollisuudet yrittäjyysopetuksessa ja yrittäjyydessä (Berglund, Lindgren \& Packendorff 2017).

\section{YRITTÄJÄMINÄSTÄ AINUT OLEMISEN TAPA?}

Kuudes yrittäjyyttä koskeva haaste on sen näkeminen itsestään selvästi ainoana mahdollisena toimintamallina ja olemisen tapana kaikille, kaikissa tilanteissa. Monessa yliopistossa, kuten Turun yliopistossa, yrittäjyysopetuksessa korostetaan yrittäjäksi ryhtymisen ohella yrittäjyysopintojen merkitystä ja yrittäjyysosaamisen tarvetta myös palkkatyöhön hakeutuvilla. Yrittäjämäisyyttä ja sisäistä yrittäjyyttä painottava kirjallisuus nostaa aloitteellisuuden ja luovuuden tai innovatiivisuuden osaamisiksi, joilla varmistutaan omasta työllistettävyydestä (Heinonen \& VentoVierikko 2002).

Tekemiemme opiskelijakyselyjen perusteella opiskelijat ovat sisäistäneet tämän ajatuksen. 


\section{VOIKO YRITTÄJYYS OLLA}

\section{VAIN YKSI MAHDOLLINEN URAVAIHTOEHTO?}

Kyselytutkimukseen vastanneet opiskelijat kokivat, että työelämä yhtäältä arvostaa yrittäämäisiä taitoja ja toisaalta ei arvosta akateemisia taitoja (Räty ym. tulossa). Yrittäjämäisten taitojen korostuminen asettaa 'yrittäjäminän' yksilön ainoaksi mahdolliseksi toiminnan ja olemisen tavaksi, joka ei mahdollista muita tapoja olla ja toimia (Korhonen 2012). Työ- ja yrittäjätiimien tutkimus on kuitenkin osoittanut, että useimmissa tilanteissa parhaita tiimejä ovat mahdollisimman heterogeeniset tiimit (Steffens, Terjesen \& Davidsson 2012). Siten ei ole juurikaan todisteita sille, että työelämässä tai edes yrittäjätiimeissä tarvittaisiin vain idearikkaita, aloitteellisia innovaattoreita. Lisäksi tarvitaan analyyttisiä, kriittisiä toimenpanijoita.

Liisa Keltikangas-Järvinen (2011) on nostanut kriittiseen keskusteluun sosiaalisuuden ihannoinnin työelämässä, esimerkiksi sosiaaliset taidot rekrytointien keskeisenä kriteerinä. Vastaavasti voimme kyseenalaistaa yrittäjämäisyyden edellytyksenä kaikkiin tehtäviin ja rooleihin sekä vallitsevana toimintatapana.

Yrittäjyyden tutkijana ja opettajana en vastusta yrittäjyyden tuomista yliopistoon ja sen tuomien mahdollisuuksien esittelyä opiskelijoille uravaihtoehtona. Haluan kuitenkin tuoda keskusteluun refleksiivisyyden tarpeen. Yrittäjyyskasvatustutkimuksen suomalainen edelläkävijä ja kehittäjä Paula Kyrö on esittänyt, että yrittäjyysopetuksen kehittäminen edel- lyttää hyvin vahvaa arvoteoreettista keskustelua ja kysymysten esittämistä. Haluammeko lisätä yrittäjyysopetusta ja edistää yrittäjyyttä? Millä tavoin yrittäjyysopetusta tarjotaan? Voimme kysyä, miksi yrittäjyyttä tarjotaan (Kyrö 2015).

Yrittäjyysopetuksen ja muun yrittäjyystoiminnan tarjonnan ohessa on samoin hyvä jatkuvasti tarkastella ja arvioida, mitä tapahtuu. Millaisia ajatuksia, ideaaleja tai itsestäänselvyyksiä yrittäjyydestä tarjoamme - tietoisesti tai vahingossa? Miten opetuksen käytännöt kutsuvat tai sulkevat pois joitakin opiskelijoita tai opiskelijaryhmiä?

Opettajille on tärkeää antaa mahdollisuuksia kehittää omaa opetustaan innovatiivisesti. Vastaavasti opiskelijoille on annettava mahdollisuus arvioida yrittäjyyden positiivisia ja negatiivisia tulemia oman tulevaisuutensa näkökulmasta. Voiko yrittäjyys olla vain yksi mahdollinen ura tai toimintatapa monien muiden joukossa? (Hytti 2018)

Kriittisyys on tärkeää kaikessa tutkimuksessa, mutta toisinaan kriittistä tutkimusta ja näkökulmaa pidetään marginaalissa ja sen oletetaan vain nostavan esiin ongelmia ja haasteita, kun vastaavasti käytännönläheisiä valtavirtanäkemyksiä pidetään ratkaisujen tuottajina. Kriittisen tutkimuksen näkökulmat ovat kuitenkin tapoja rakentaa ja tuoda yrittäjyyttä yliopistoon yhteiskunnallisesti ja sosiaalisesti kestävästi.

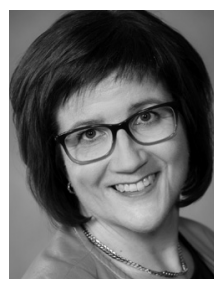

ULLA HYTTI

KTT, tutkimusjohtaja, dosentti johtamisen ja yrittäjyyden laitos Turun yliopiston kauppakorkeakoulu 
Berglund, K., Lindgren, M., \& Packendorff, J. (2017). Responsibilising the next generation: Fostering the enterprising self through de-mobilising gender. Organization 24(6), 892-915. DOI: https://doi. org/10.1177/1350508417697379.

Berglund, K. \& Verduyn, K. (toim.) (2018). Revitalizing Entrepreneurship Education: Adopting a Critical Approach in the Classroom. Oxon \& New York: Roudledge.

Blank, S. (2013a). The Four Steps to the Epiphany: Successful Strategies for Products that Win. BookBaby.

Blank, S. (2013b). Why the Lean Start-up Changes Everything. Harvard Business Review 91(5), 63-72.

Heilbrunn, S., \& Almor, T. (2014). Is entrepreneurship education reproducing social inequalities among adolescents? Some empirical evidence from Israel. The International Journal of Management Education 12(3), 445-455.

Heinonen, J., \& Vento-Vierikko, I. (2002). Sisäinen yrittäjyys: Uskalla, muutu, menesty. Helsinki: Talentum.

Hytti, U. \& Heinonen, J. (2013). Heroic and humane entrepreneurs: identity work in entrepreneurship education. Education+Training 55(8/9), 886-898.

Hytti, U. (2018). Critical entrepreneurship education: a form of resistance to McEducation? Teoksessa Berglund, K. \& Verduyn, K. (eds.). Revitalizing Entrepreneurship Education: Adopting a Critical Approach in the Classroom. London: Routledge, 228-234.

Hägg, G. (2017). Experiential entrepreneurship education: Reflective thinking as a counterbalance to action for developing entrepreneurial knowledge. Dissertation. Lund: Lund University.

Ikonen, R. (2006). Yrittäjyyskasvatus: kansalaisen taloudellista autonomiaa etsimässä. SoPhi, (102), Helsinki-Jyväskylä: Minerva Kustannus Oy.

Jabbar, A., \& Hardaker, G. (2013). The role of culturally responsive teaching for supporting ethnic diversity in British University Business Schools. Teaching in Higher Education 18(3), 272-284.

Jarillo, J. C. (1989). Entrepreneurship and Growth: The Strategic Use of External Resources. Journal of Business Venturing 4(2), 133-147.

Jones, S., \& Warhuus, J. P. (2018). "This class is not for you" An investigation of gendered subject construction in entrepreneurship course descriptions. Journal of Small Business and Enterprise Development 25(2), 182-200.

Keltikangas-Järvinen, L. (2011). Sosiaalisuus ja sosiaaliset taidot. Helsinki: WSOY.

Korhonen, M. (2012). Yrittäjyyttä ja yrittäjämäisyyttä kaikille. Uusliberalistinen hallinta, koulutettavuus ja sosiaaliset erot peruskoulun yrittäjyyskasvatuksessa. Publications of the University of Eastern Finland, Dissertations in Education, Humanities, and Theology No 29. Joensuu: Itä-Suomen yliopisto.
Korkeakoulujen yrittäjyyssuositukset (2018) Arene, Unifi ja Suomen Yrittäjät. http://www.unifi.fi/wp-content/ uploads/2018/12/Yritt\%C3\%A4jyyssuositukset.pdf.

Kozlinska, I. (2016). Evaluation of the Outcomes of Entrepreneurship Education Revisited. Annales Universitatis Turkuensis Oeconomica: Series E:10. Dissertation. Turku: Turun yliopisto.

Kyrö, P. (2015). The conceptual contribution of education to research on entrepreneurship education.

Entrepreneurship \& Regional Development 27(9-10), 599-618.

Marlow, S., \& McAdam, M. (2012). Analyzing the Influence of Gender upon High-Technology Venturing within the Context of Business Incubation. Entrepreneurship Theory and Practice 36(4), 655-676.

Peredo, A. M., \& McLean, M. (2006). Social entrepreneurship: A critical review of the concept. Journal of world business 41(1), 56-65.

Rae, D. (2014). Graduate Entrepreneurship and Career Initiation in the 'New Era'economy. Journal of general management 40(1), 79-95.

Ries, E. (2011). The Lean Startup: How Today's Entrepreneurs Use Continuous Innovation to Create Radically Successful Businesses. New York: Crown Books.

Ritzer, G. (1998). The McDonaldization Thesis: Explorations and Extensions. London: Sage.

Räty, H., Kozlinska, I., Kasanen, K., Siivonen, P., Komulainen, K.\& Hytti, U. (tulossa). Being stable and getting along with others: Perceived ability expectations and employability among Finnish university students. Hyväksytty julkaistavaksi julkaisussa Social Psychology of Education.

Seikkula-Leino, J. (2007). Opetussuunnitelmauudistus ja yrittäjyyskasvatuksen toteuttaminen. Opetusministeriön julkaisuja 2007:28. http://julkaisut. valtioneuvosto.fi/bitstream/handle/10024/79409/ opm28.pdf. Helsinki: Opetusministeriö.

Shane, S. (2009). Why encouraging more people to become entrepreneurs is bad public policy. Small Business Economics 33(2), 141-149.

Steffens, P., Terjesen, S., \& Davidsson, P. (2012). Birds of a feather get lost together: new venture team composition and performance. Small Business Economics 39(3), 727-743.

Sutela, H. \& Pärnänen, A. (2018) Yrittäjät Suomessa 2017. Helsinki: Tilastokeskus.

Wilson, F., Kickul, J., \& Marlino, D. (2007). Gender, Entrepreneurial Self-Efficacy, and Entrepreneurial Career Intentions: Implications for Entrepreneurship Education. Entrepreneurship Theory and Practice 31(3), 387-406. 